\title{
B-cell Lymphoma in retrieved femoral heads: a long term follow up Eline W Zwitser ${ }^{1}$, Arthur de Gast ${ }^{1}$, Mirjam JA Basie ${ }^{1}$, Folkert J van Kemenade ${ }^{2}$ and Barend J van Royen*1
}

\author{
Address: ${ }^{1}$ Department of Orthopaedic Surgery, VU University Medical Center, Amsterdam, The Netherlands and ${ }^{2}$ Department of Pathology, VU \\ University Medical Center, Amsterdam, The Netherlands \\ Email: Eline W Zwitser - ewzwitser@hotmail.com; Arthur de Gast - a.degast@vumc.nl; Mirjam JA Basie - mbe500@student.vu.nl; Folkert J van \\ Kemenade - f.vankemenade@vumc.nl; Barend J van Royen* - bj.vanroyen@vumc.nl \\ * Corresponding author
}

Published: 20 May 2009

BMC Musculoskeletal Disorders 2009, 10:53 doi:10.1 186/147I-2474-10-53
Received: 4 September 2008

Accepted: 20 May 2009

This article is available from: http://www.biomedcentral.com/I47I-2474//0/53

(C) 2009 Zwitser et al; licensee BioMed Central Ltd.

This is an Open Access article distributed under the terms of the Creative Commons Attribution License (http://creativecommons.org/licenses/by/2.0), which permits unrestricted use, distribution, and reproduction in any medium, provided the original work is properly cited.

\begin{abstract}
Background: A relatively high incidence of pathological conditions in retrieved femoral heads, including a group of patients having low grade B-cell lymphoma, has been described before. At short term follow up none of these patients with low-grade B-cell lymphoma showed evidence of systemic disease. However, the long term follow up of these patients is not known.

Methods: From November 1994 up to and including December 2005 we screened all femoral heads removed at the time of primary total hip replacement histopathologically and included them in the bone banking protocol according to the guidelines of the American Associations of Tissue Banks (AATB) and the European Association of Musculo-Skeletal Transplantation (EAMST). We determined the percentage of B-cell lymphoma in all femoral heads and in the group that fulfilled all criteria of the bone banking protocol and report on the long-term follow-up.

Results: Of 852 femoral heads fourteen (1.6\%) were highly suspicious for low-grade B-cell lymphoma. Of these 852 femoral heads, 504 were eligible for bone transplantation according to the guidelines of the AATB and the EAMST. Six femoral heads of this group of 504 were highly suspicious for low-grade B-cell lymphoma (I.2\%). At long term follow up two $(0.2 \%)$ of all patients developed systemic malignant disease and one of them needed medical treatment for her condition.

Conclusion: In routine histopathological screening we found variable numbers of low-grade B-cell lymphoma throughout the years, even in a group of femoral heads that were eligible for bone transplantation. Allogenic transmission of malignancy has not yet been reported on, but surviving viruses are proven to be transmissible. Therefore, we recommend the routine histopathological evaluation of all femoral heads removed at primary total hip arthroplasty as a tool for quality control, whether the femoral head is used for bone banking or not.
\end{abstract}

\section{Background}

Allograft donor bone is successfully used in reconstructive tumor surgery and revision of total hip arthroplasties $[1,2]$. Bone banks collect femoral heads according to the safety procedures of the American Associations of Tissue
Banks (AATB) and the European Association of MusculoSkeletal Transplantation (EAMST) [3,4]. These constantly updated guidelines are of the utmost importance in order to prevent the transmission of infectious diseases. 
Despite these extensive procedures, there have been recent reports of living cells within donor tissue after routine cryopreservation [5-7]. The potential risk of transmission of diseases from donor to recipient by these surviving cells remains uncertain, but there have been several reports on the development of infectious diseases due to the transplantation of contaminated allograft bone [8-14]. Previously we, and another group, recommended routine histological examination in the screening protocol because of a relatively high percentage of pathological conditions in retrieved femoral heads, including a group of patients having low grade B-cell lymphoma $[15,16]$. At short term follow up none of the patients with low-grade B-cell lymphoma in the femoral head showed evidence of systemic disease. However, the clinical consequences of these findings remained unknown. Therefore we continued our prospective study to screen histopathologically all retrieved femoral heads after total hip arthroplasty, including those that were not suitable for bone banking. We determined the percentage of B-cell lymphoma in all femoral heads, and in the group that met all criteria of the bone banking protocol, and will now report on the longterm follow-up.

\section{Methods}

From November 1994 through December 2005 all femoral heads removed at the time of primary total hip replacement were collected according to the guidelines of the AATB and EAMST $[3,4]$. All patients gave written and signed informed consent. They were screened by a questionnaire covering their medical, social and sexual history. The questionnaire was based on pre-existing forms, followed the guidelines of the AATB and EAMST, and was written in the patient's native language. Additionally, the patients were interviewed by a doctor. A thorough physical and routine blood examination was performed. Blood was collected to determine the blood group, Rhesus factor, and white blood cell count. Screening tests were performed to exclude syphilis, HBV and hepatitis $\mathrm{C}$ virus (HCV), cytomegalovirus (CMV), HIV1 and 2 and HTLV type 1. An increased ESR was also used as a criterion for exclusion. All donors were retested for HIV1 and 2, syphilis, HBV, HCV and HTLV1 six months after the donation, taking into account the negative window period. After resection of the femoral heads, swabs from bone and capsule were taken for aerobic and anaerobic cultures. A core bone biopsy specimen $\left(1 \mathrm{~cm}^{3}\right)$ and a part of the capsule were retrieved for histopathological examination. Cores or biopsies were, in general, too big for electrolytical decalcification, as is routine in the laboratory for trephine biopsies. Thus they were decalcified in Kirstensen' solution in a daily controlled fashion. After decalcification, biopsies were routinely processed and microscopy was performed on Hematoxylin and Eosin. When required for more precise examination (i.e. lymphocytic collections that were monotoneous) additional stains and immunohistochemistry were performed to confirm diagnosis and, if possible, classified.

Grafts were stored at $-80^{\circ} \mathrm{C}$ and six months later another blood examination followed. Earlier we described our bone bank screening procedure in detail [15]. Femoral heads of patients which were excluded somewhere in this bone banking selection process were sent for routine histopathological examination only.

Non-Hodgkin Lymphoma was diagnosed according to routine diagnostic procedures in the laboratory by expert hematopathologists. Criteria for diagnosis were an increase in lymphoid cells in general characterized by an interstitial pattern of infiltration, or paratrabecular localization of two or more nodules to packed marrow of cells with short chain restriction (kappa or Lambda) and uniform B-cell marker (CD20, CD79a, CD23 expression). In cases of concomitant elevated peripheral white blood cell counts, CLL was diagnosed.

We determined the percentage of low-grade B-cell lymphoma in all femoral heads and in the group that was suitable according to the bone banking protocol. Patients having low-grade B-cell lymphoma in the femoral head were referred to a hematologist-oncologist for further evaluation. Follow up of these patients consisted of clinical and radiological assessment on a yearly basis, review of hospital files and contact with family doctors. We assessed patients who had symptoms of systemic disease and who were treated by other physicians.

\section{Results}

From November 1994 to December 2005 we obtained 852 femoral heads removed at the time of primary total hip replacement from 737 patients (205 men, 532 women), mean age 69 years (Range 23 to 94 years). We reported earlier on the first 137 of these femoral heads [15]. Fourteen of 852 femoral heads were highly suspicious of low-grade B-cell lymphoma (1.6\%). These fourteen femoral heads were retrieved from 13 donors. Mean age of these donors was 67 years (Range 51-79 years). Of 852 femoral heads, 504 fulfilled all criteria for donation according to the existing guidelines of EAMST and AATB. A total of 348 femoral heads were discarded because of a positive donor history (questionnaire), an increased ESR, or positive serological, histological or bacterial tests. They were also discarded if malignant disease was diagnosed within six months of donation. Some femoral heads have been rejected because of incomplete information from the screening tests. Six of 504 allografts fulfilling all criteria for donation were excluded based solely on the histopathological features of B-cell lymphoma (1.2\%). These six femoral heads, retrieved from six different donors, 
were also excluded from clinical use and donation. We found variable numbers of low-grade B-cell lymphoma throughout the years. The distribution of low-grade B-cell lymphoma for each year is shown in figure 1 . We performed long term follow up at a median of 7.2 years (Range 1-12 years). In this long term follow up one patient had developed a B-cell lymphoma in a lymph vessel in the inguinal region on the contralateral side, three years after the histopathological diagnosis of low-grade Bcell lymphoma was established. She underwent a lymph node excision and started with chemotherapy and radiotherapy. Currently this patient has been stable (non-progressive disease) for three years but continues to be monitored by a hematologist-oncologist. Another patient developed chronic lymphatic leukemia. No treatment was indicated but she is under the supervision of a hematologist-oncologist. Three other patients are still being monitored on a yearly base by a hematologist. They have yet to develop malignant disease.

\section{Discussion}

In routine histopathological screening of 852 femoral heads, throughout the years we have found fourteen lowgrade B-cell Non-Hodgkin Lymphoma (NHL) in thirteen patients. Even in the group of 504 femoral heads that were eligible for bone transplantation, six femoral heads in six patients were suspicious of low-grade B-cell lymphoma. We have performed a long term follow up of these thirteen patients in which we diagnosed low-grade B-cell NHL in their removed femoral heads. Two patients developed systemic malignant disease; one of them needed medical treatment for her condition. Three other patients are evaluated on a yearly basis by a hematologist.

Non-Hodgkin lymphoma (NHL) is a malignancy of the lymphatic system, caused by uncontrolled proliferation of B- or T-cell lymphocytes. It is relatively uncommon, but the standardized incidence has increased dramatically in the past few decades and is expected to increase by an additional $36.1 \%$ between 2000 and $2020[17,18]$. Extensive research to assess this increase shows a diversity of potential risk factors, such as diet, environmental and occupational factors, hair dye, viruses, hepatitis C infection, immunosuppression and blood transfusion. However, explanations accounting for all increases are not yet available [19-27]. Treatment of patients with NHL depends on histological type, clinical stage and prognostic group [28]. In low-grade B-cell lymphoma, by the time of diagnosis the disease is widespread and therefore incurable, but only a small group of these patients develops systemic malignant disease. Therefore a watch and wait approach is indicated. Palliative chemotherapy can be started at the time the patient presents with systemic manifestation of disease [29]. In our study one of the thirteen patients diagnosed with low-grade B-cell lymphoma developed systemic malignant disease for which she needed medical treatment. Four other patients are being monitored on a yearly basis by a hematologist.

Recent literature questions the necessity of routine histopathological examination of retrieved femoral heads. There are studies that find the cost-performance ratio of routine histopathological evaluation unfavorable because of the little clinical significance in changes of treatment from the diagnoses found [30-34]. Other studies recommend routine evaluation because of a recognized incidence of unsuspected, malignant diagnoses and as a tool for quality control $[15,16,35]$. The significance of these diagnoses is still unknown, but patients with neoplastic histopathological findings need monitoring and follow up. To our best knowledge, transmission of low grade Bcell lymphoma by bone donation has never been reported in medical literature. On the other hand, it has never been proven that bone with a (low grade) hematologous neoplasm is not transmissible by allogenic bone transplantation to an otherwise healthy recipient.

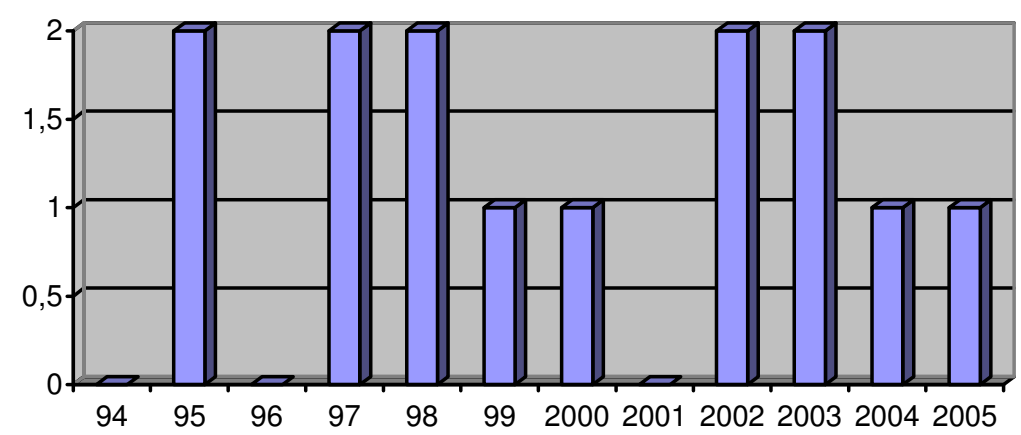

anumber of low grade B cell lymphoma

Figure I

Distribution of low grade B cell lymphoma found in retrieved femoral heads throughout the years in routine histopathological screening. 


\section{Conclusion}

In conclusion, we found variable numbers of low-grade Bcell lymphoma throughout the years in routine histopathological screening of femoral heads retrieved from patients treated by total hip arthroplasty, even in a group that was eligible for bone transplantation. Two patients developed systemic malignant disease; one of them needed medical treatment for her condition. Three other patients are still evaluated on a yearly basis by a hematologist. Therefore, we recommend the routine histopathological evaluation of all femoral heads removed during elective total hip arthroplasty as a tool for quality control, whether the femoral head is used for bone banking or not. In addition, all patients with neoplastic histopathological findings need monitoring and follow up.

\section{Competing interests}

The authors declare that they have no competing interests.

\section{Authors' contributions}

All authors have been involved in the development of the study design and research protocols. BJvR and AdG participated in the general coordination of the study and corrected the manuscript. EWZ and $M J A B$ carried out data collection and drafted the manuscript. FJvK was responsible for the pathology. All authors read and corrected draft versions of the manuscript and approved the final manuscript.

\section{References}

I. Slooff TJ, Buma P, Schreurs BW, Schimmel JW, Huiskes R, Gardeniers J: Acetabular and femoral reconstruction with impacted graft and cement. Clin Orthop Relat Res 1996, 324:108-I5.

2. Mankin HJ, Gebhardt MC, Jennings LC, Springfield DS, Tomford WW: Long-term results of allograft replacement in the management of bone tumors. Clin Orthop Relat Res 1996, 324:86-97.

3. American Association of Tissue Banks: Standards for tissue banking. [http://www.aatb.org].

4. European Association for Musculo-Skeletal Transplantation: Standards for musculo-skeletal tissue banking. [http:// www.eatb.org].

5. Weyts FA, Bos PK, Dinjens WN, van Doorn WJ, van Biezen FC, Weinans $H$, et al.: Living cells in I of $\mathbf{2}$ frozen femoral heads. Acta Orthop Scand 2003, 74:66 I-664.

6. Heyligers IC, Klein-Nulend J: Detection of living cells in nonprocessed but deep-frozen bone allografts. Cell Tissue Bank 2005, 6:25-31.

7. Simpson D, Kakarala G, Hampson K, Steele N, Ashton B: Viable cells survive in fresh frozen human bone allografts. Acta Orthop 2007, 78:26-30.

8. Tomford WW: Transmission of disease through transplantation of musculoskeletal allografts. J Bone Joint Surg Am 1995, 77: $1742-1754$.

9. Shutkin NM: Homologous-serum hepatitis following the use of refrigerated bone-bank bone. J Bone Joint Surg Am 1954, 36A: $160-162$.

10. Patel $R$, Trampuz A: Infections transmitted through musculoskeletal-tissue allografts. N Engl J Med 2004, 350:2544-2546.

II. Li CM, Ho YR, Liu YC: Transmission of human immunodeficiency virus through bone transplantation: a case report. J Formos Med Assoc 200I, 100:350-35I.

12. Karcher HL: HIV transmitted by bone graft. BMJ 1997, 3 14:1300.
13. Conrad EU, Gretch DR, Obermeyer KR, Moogk MS, Sayers M, Wilson JJ, et al.: Transmission of the hepatitis-C virus by tissue transplantation. J Bone Joint Surg Am 1995, 77:214-224.

14. Centers for Disease Control (CDC): Transmission of HIV through bone transplantation: case report and public health recommendations. MMWR Morb Mortal Wkly Rep 1988, 37:597-599.

15. Sugihara S, van Ginkel AD, Jiya TU, Van Royen BJ, van Diest PJ, Wuisman PI: Histopathology of retrieved allografts of the femoral head. J Bone Joint Surg Br 1999, 8 I:336-34l.

16. Palmer SH, Gibbons CL, Athanasou NA: The pathology of bone allograft. J Bone Joint Surg $\mathrm{Br}$ 1999, 8 I:333-335.

17. Coebergh JWW, Heijden LH van der, Janssen-Heijnen MLG, eds: Cancer incidence and survival in the Southeast of the Netherlands 1955-1994: A report from the Eindhoven Cancer Registry. Integraal Kankercentrum Zuid. Eindhoven 1995.

18. Lister EA, Coffier B, Armitage JO: Non-Hodgkin's lymphoma. In Clinical Oncology 3rd edition. Edited by: Abeloff MD, Armitage JO, Lichter AS, Niederhuber JE, Kastan MB, McKenna WG. Philadelphia, $\mathrm{Pa}$. Elsevier; 2004:2985-30I4.

19. Hartge P, Devesa SS: Quantification of the impact of known risk factors on time trends in non-Hodgkin's lymphoma incidence. Cancer Res 1992, 52:5566s-5569s.

20. Muller AM, lhorst G, Mertelsmann R, Engelhardt M: Epidemiology of non-Hodgkin's lymphoma (NHL): trends, geographic distribution, and etiology. Ann Hematol 2005, 84: I-I 2.

21. Talamini R, Polesel J, Montella M, Dal Maso L, Crovatto M, Crispo A, et al.: Food groups and risk of non-Hodgkin lymphoma: a multicenter, case-control study in Italy. Int J Cancer 2006, I | 8:287|-2876.

22. Pearce N, Bethwaite P: Increasing incidence of non-Hodgkin's lyphoma: occupational and environmental factors. Cancer Res 1992, 52:5496s-5500s.

23. Mele A, Pulsoni A, Bianco E, Musto P, Szklo A, Sanpaolo MG, et al.: Hepatitis $C$ virus and B-cell non-Hodgkin lymphomas: an Italian multicenter case-control study. Blood 2003, 102:996-999.

24. Negri E, Little A, Boiocchi M, La Vecchia C, Franceschi S: B-cell nonHodgkin's lymphoma and hepatitis $C$ virus infection: a systematic review. Int J Cancer 2004, I I I: I-8.

25. Brandt L, Brandt J, Olsson H, Anderson H, Moller T: Blood transfusion as a risk factor for non-Hodgkin lymphoma. $\mathrm{Br} J \mathrm{Cancer}$ 1996, 73: I|48-I|5|.

26. Zur HH: Viruses in human cancers. Science I99I, 254:I I67-II 73.

27. Devesa SS, Fears T: Non-Hodgkin's lymphoma time trends: United States and international data. Cancer Res 1992 , 52:5432s-5440s.

28. Doorduijn JK, Sonneveld P: [Diagnosis and treatment of nonHodgkin lymphoma in elderly patients]. Ned Tijdschr Geneeskd 1997, | 41:2152-2157.

29. Lundquist DM, Stewart FM: An update on non-Hodgkin's lymphomas. Nurse Pract 1994, 19:49-4I.

30. Kocher MS, Erens G, Thornhill TS, Ready JE: Cost and effectiveness of routine pathological examination of operative specimens obtained during primary total hip and knee replacement in patients with osteoarthritis. J Bone Joint Surg Am 2000, 82-A: I53I-I535.

31. Meding JB, Ritter MA, Jones NL, Keating EM, Faris PM: Determining the necessity for routine pathologic examinations in uncomplicated total hip and total knee arthroplasties. J Arthroplasty 2000, I 5:69-7I.

32. Lawrence T, Moskal JT, Diduch DR: Analysis of routine histological evaluation of tissues removed during primary hip and knee arthroplasty. J Bone Joint Surg Am 1999, 81:926-931.

33. Raab SS, Slagel DD, Robinson RA: The utility of histological examination of tissue removed during elective joint replacement. A preliminary assessment. J Bone Joint Surg Am 1998 , 80:331-335

34. Campbell ML, Gregory AM, Mauerhan DR: Collection of surgical specimens in total joint arthroplasty. Is routine pathology cost effective? J Arthroplasty 1997, I 2:60-63.

35. Lauder AJ, Cheatham SA, Garvin KL: Unsuspected non-Hodgkin's lymphoma discovered with routine histopathology after elective total hip arthroplasty. J Arthroplasty 2004, I 9: I05. 


\section{Pre-publication history}

The pre-publication history for this paper can be accessed here:

http://www.biomedcentral.com/1471-2474/10/53/pre

pub

Publish with Bio Med Central and every scientist can read your work free of charge

"BioMed Central will be the most significant development for disseminating the results of biomedical research in our lifetime. " Sir Paul Nurse, Cancer Research UK

Your research papers will be:

- available free of charge to the entire biomedical community

- peer reviewed and published immediately upon acceptance

- cited in PubMed and archived on PubMed Central

- yours - you keep the copyright 